\title{
O sal e a selva
}

Felipe Luiz Gomes Figueira ${ }^{1}$

Eu fotografei o êxodo de trabalhadores, o extermínio de povos, as situações mais miseráveis possíveis.

Eu deixei um pouco do meu conforto de lado para morar junto aos Zoés

e comer o mumu em Papa Nova Guiné.

Ao longo das minhas peregrinações, os ricos de todo mundo me disseram:

"E quanto a nós? Até quando tuas lentes nos desprezarão?".

Miseráveis,

foram os países de Primeiro Mundo que eu sempre, sempre registrei.

Eis a revelação:

nada do que vemos dentro de um supermercado

foi ali produzido.

Todo meu trabalho não chega a um segundo

se contado pelo tic-tac de um relógio.

Mas, num universo em verso mais importa

a qualidade, a dramática mocidade que,

apesar de tudo, nunca morre.

Não se autoproponha uma tese

para confirmá-la num cenário inverso.

Minhas três lentes tornam-se frequentemente uma dialética

onde desapareço entre as populações

e com meus poucos filmes esfacelo toda dialética

para reencontrar a essência.

Meu branco e negro,

meu branco contra o negro

é uma luz na contramão,

é uma tela que só quem se abaixa na pinguela

para o outro pisar pode colorir;

é um tiro contra uma caça

que eu só, só eu quero preservar.

Meu flash é a própria estética da flecha.

\footnotetext{
${ }^{1}$ Docente do Instituto Federal do Paraná, Campus Paranavaí. Doutor em Educação pela UNESP-Marília, pósdoutorando em História pela Universidade Federal de Ouro Preto.
} 